\title{
Current Issues And Barriers Of Maintenance Management Practices For Public Facilities In Malaysia
}

\author{
Sylvia Gala Mong, Sarajul Fikri Mohamed, Mohd. Saidin Misnan
}

\begin{abstract}
There are significant challenges for local authorities in Malaysia in providing and managing the public facilities for the satisfaction of stakeholders. Therefore, the local authorities need to maintain the facilities to ensure the public to be able to use them effectively and comfortably. However, over the years, the local authorities faced countless critics and complaints regarding their performance in managing the facilities from the public. Moreover, the local authorities confronted maintenance cost issues while maintaining and operating the facilities, which lead to ineffective management. This unfortunate situation has tarnished the image of the local authorities, which supposedly act as a service provider to the public in their regions. This paper investigates the current maintenance management practices by the local authorities and to identify the barriers encountered during the implementation of maintenance management. The study utilized a comprehensive sample by distributing 149 questionnaires to the maintenance department of local authorities. The results of current practices were analyzed by using the mean value score and Relative Importance Index (RII) while the barriers were examined using the mean value score and Severity Index (SI). The results indicated that the current practices of the maintenance management conducted by the local authorities did not achieve the level of satisfaction which leads to the issues of ineffective maintenance management and the barriers that faced by the local authorities shows that building characteristics, vandalism and human factors have become the significant factors of maintenance cost issues. Consequently, the study provides the recommendation of directions and guidance towards the best practices of maintenance management to accomplish the maintenance efficiency and value for money throughout various strategies of improvements.
\end{abstract}

Index Terms: Maintenance practices, barriers, local authorities, maintenance cost

\section{INTRODUCTION}

There are many challenges and obstacles encountered by the government to ensure the buildings and landmarks are well-managed and maintained as some concentration has been focused on the very little aspects. Facilities building must be managed and secured so they can be in an immaculate condition and well-functioned. The expectations of the users, especially the public, are rising, and their needs keep on changing towards the better quality of life. Past and current practices of maintenance management in both private and government sectors have shown the implication of maintenance action are taken when the assets and equipment are damaged and fail to function. The demand for maintenance is predicted due to the impending or actual failure of the equipment and assets. Since most of the assets and the equipment are essential for the organization to run their business, they try to ensure that the components are free from failing to operate.

Therefore, many companies and organization started to take maintenance as a severe matter to keep the elements in a proper working condition (1). Maintenance is crucial for delivering a better-built environment for the customers.

The local authority is the giant holders of the assets which signifies that they are accountable to ensure the facilities and assets are in the excellent condition. The emergent complexity of the obligations by the local authority is demonstrating more challenges for managers all over Malaysia (2). Despite the fact that each local authority has different objectives and standards, the managers are obligated to provide the facilities and services to build and support the sustainable societies for their residents (3). In recent years, there has been a flood of positive and negative reviews on their capability in terms of financial and management sustainability. As the service provider, local authorities are responsible for managing and maintaining the public facilities to fulfil and satisfy the general needs. Additionally, to achieve sustainable and cost-effective maintenance, the local authorities must be able to implement the best practices of maintenance management. The purpose of this paper is to empirically examine the current practices of maintenance management for public facilities by local authorities and the barriers faced by them.

Recent years has shown that the local authorities faced enormous challenges due to the development of areas and the increased in responsibilities of management. It is undeniable that the building cannot be protected from the weather condition and ageing factor. Nonetheless, by having proper and adequate maintenance activities, the structure can safeguard the state of the buildings (4). Recent studies have indicated that successful maintenance management is depending on effective maintenance management practices (5). However, numerous critics and complaints made on the local authority regarding the control of their assets and facilities have been reported (Fig. 1). 
Moreover, the government has spent a tremendous amount of money for the local authorities to focus on maintaining the current assets and reduce the numbers of incidents related to building failures (6). The cost of maintenance has become the primary concern which becomes the burden to the local authorities as they are only depending on the grants from the federal and state government to add up their source of revenue to support the maintenance budget (7). Lack of maintenance culture and awareness had made it even worse where the maintenance activities were only implemented during the emergency, and no priority was given to encounter the maintenance issues (8).

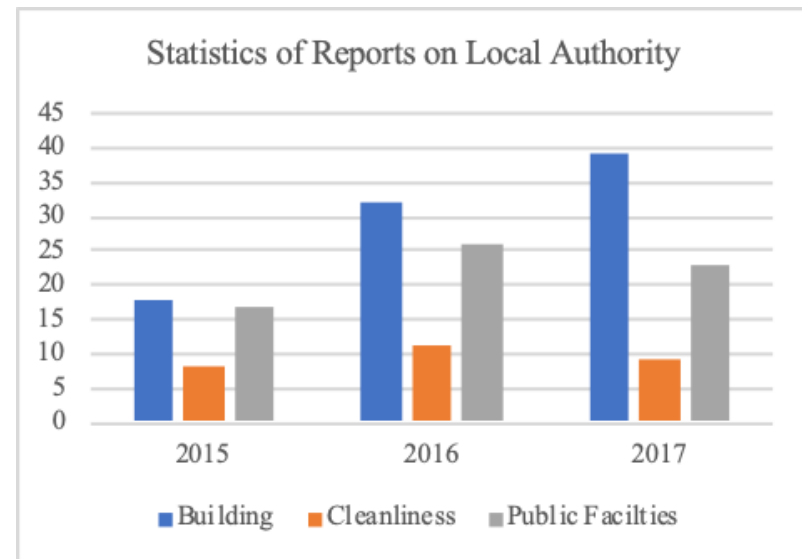

Fig. 1 Statistics of reports on local authority (9)

More and more local authorities are coming into a realization of the importance of financially sustainable and maintenance practices by local authorities need to be examined to identify the factors that contribute to the maintenance issues and barriers in implementing the maintenance activities. This paper aims to assess the current maintenance management practices by local authorities in Malaysia to improve the understanding of its practices and effectiveness. The objectives of this study are:

- To examine the current maintenance management practices adopted by the local authorities for public facilities; and

- $\quad$ To identify the barriers faced by the maintenance department in implementing maintenance management practices.

\section{THE MAINTENANCE MANAGEMENT CONCEPT}

Various definitions have been made on maintenance with the same objective; to upkeep and sustain the better condition of the assets and components. According to Wordsworth and Lee (10), maintenance is described as "the effort in connection with different technical and administrative actions, intended to retain an item in or to restore it to a state in which it can perform a required function". Additionally, maintenance is defined as the "work undertake to keep, restore or improve every part of the building, its services and surroundings to an acceptable standard and to sustain the utility and value of the building" (11). best practices management. Therefore, the current

Hence, it goes along the way in having the better condition of the assets and components to support the business of the organization. The responsibilities of the maintenance department are broad as they need to fulfil the maintenance required to guarantee the building assets can perform effectively and efficiently (12). These definitions highlight the importance of maintenance management; while keeping and maintaining the structure, it can operate efficiently and can reduce the numbers of breakdowns.

\section{A. Classification of Maintenance Management}

Appropriate identification of defects and the implementation of remedial measure based on the technical knowledge can contribute to effective building maintenance. Seeley (11) has categorized the maintenance as predictable and avoidable; predictable maintenance is the regular periodical maintenance that carries out to retain the performance of the building and repair and replace the components while preventive maintenance is the maintenance required to rectify failures due to incorrect design and installation or faulty materials. Moreover, some researcher also has classified the maintenance management into planned and unplanned maintenance, which consists of many approaches (13). Fig. 2 shows the standard approaches to maintenance management.

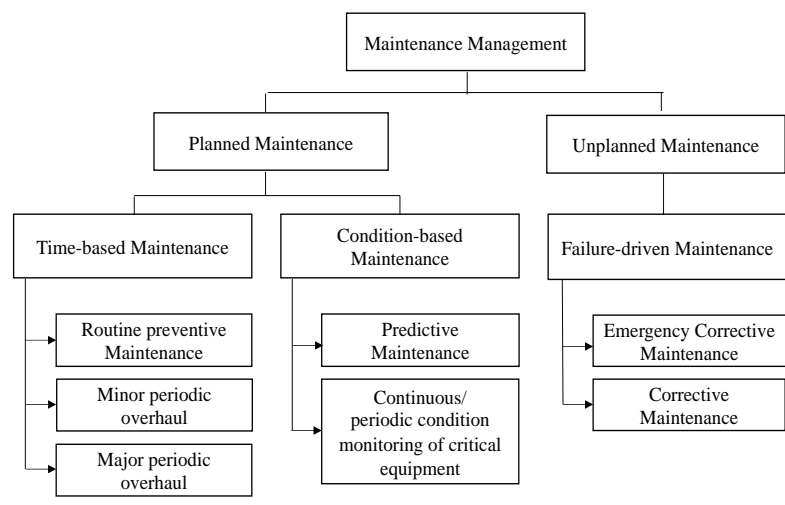

Fig.2 Common maintenance management approaches (14) (15)

\section{B. Best Practices of Maintenance Management}

In the built environment, the maintenance affects everyone continually as in homes, offices, factories, facilities and equipment that people depend not only for comfort but also for the economics purposes. The maintenance managers and personnel need to carry out adequate maintenance management to avoid additional waste of materials, labor and money since there will be a probability to execute the work again. Table I shows the elements of maintenance practices that needed to ensure effective management by various authors. Maintenance department needs to emphasize on the strategic aspects of their administration during the maintenance activities' execution. Leadership and commitment of top management is the key success towards the best outcome of the productivity as they are the one who will lead the 
management towards achieving the mission and vision of the organization (16).

Lee and Scott (12) emphasized that the policy plays the essential keys as it contains all the standard and guidelines to implement all the management task and description of the responsibilities of the maintenance personnel. Furthermore, there is a vital need of more uniformity in the way of having recordkeeping maintenance data and better feedback of data information on the performance of the materials, spare parts and running cost of the building to ensure the effective management has been conducted (17). The formulation of the comprehensive maintenance plan must include all related sources such as skilled personnel with suitable training and skill development, quality material and spare parts, budgets and also data information of maintenance. Through the feedback of performance assessment, the improvement can be improved from time to time to achieve sustainability of cost and quality for maintenance.

Table I Elements for best practices of maintenance management

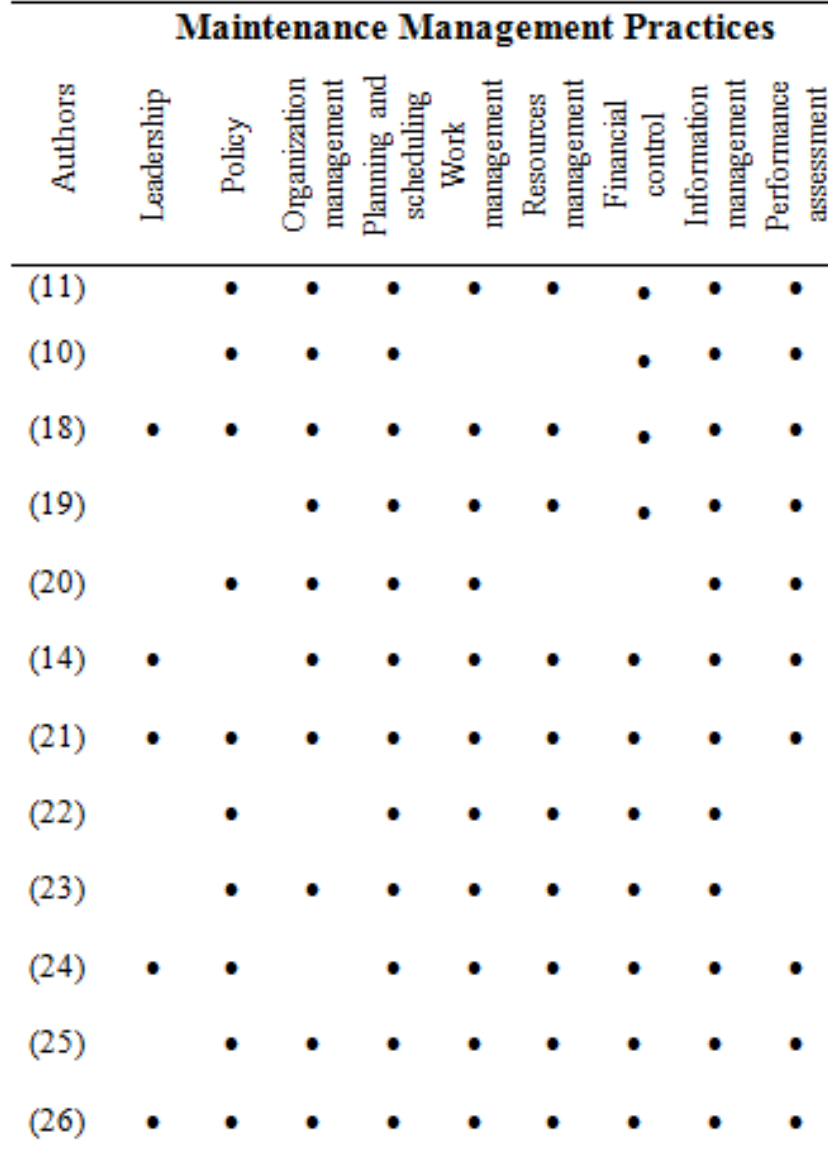

C. Barriers in Implementation of Maintenance Management

Many previous pieces of research have shown poor maintenance management that contribute to cost, quality and organization performance. Poor maintenance management caused by various factors such as complexity of building characteristics, variable maintenance process, overlapping responsibilities of maintenance personnel, distinctive regulations and manuals and other unpredictable situation that prevent the maintenance management from being implemented effectively. Most of the barriers affected the cost of maintenance as the materials and component for repairs and replacement are usually very costly such as the mechanical installations and high technology equipment (27). Moreover, outdated formulation of budget preparation shows that the money unable to support the maintenance activities (7). Vandalism also is the significant barrier that causes the difficulties to the maintenance department to execute multiple maintenance works and very costly (28). The maintenance department must be able to identify the potential barrier and evaluate the effects to implement the effective maintenance plans (29).

\section{METHODOLOGY}

The literature review and survey were adopted in the study to achieve the objectives of the research stated earlier. First, the elements of best practices were identified and classified as per Table 1 through a comprehensive literature review. These elements were included in the questionnaires as the variables. Data were gathered through the survey to examine the current practices of the maintenance personnel in the maintenance department of local authorities. The questionnaires were distributed to 149 local authorities in Malaysia. The survey consists of three sections. The first section is on the demographic background of the respondent, and the second section includes the current practices of maintenance management for public facilities that the respondents need to score the importance of implementation in their organization ranging from scale 1 (Very not important) to 5 (Very important). Section 3 requires the respondents to evaluate the severity level of the barriers faced by them during the execution of maintenance management ranging from scale 1 (Not very severe) to 5 (Very severe).

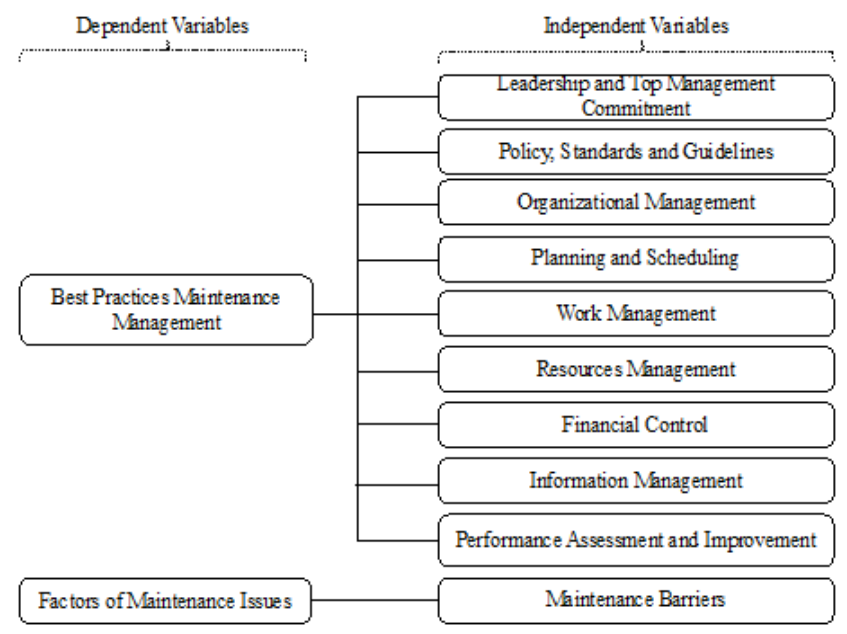

Fig.3 The variables used in the study

Fig. 3 shows the dependent and independent variables used in the study to achieve the stated objectives. Next, the data were analyzed by using frequency, relative importance index and severity index, taking in views from maintenance department personnel. Agreement on the ranking of the important practices in the maintenance management and barriers were also demonstrated. Recommendations for improving the current practices and minimizing the potential barriers occurrence were emphasized in view of the results 
International conference on Recents Advancements in Engineering and Technology (ICRAET-18) |15th and 16th March 2019|Siddhartha Institute of Technology \& Sciences, Telangana, India.

of the study.

\section{RESULTS AND FINDINGS}

The gathered data are analyzed using the Statistical Package for Social Science (SPSS). The non-parametric statistical testing utilizing the descriptive statistics and indices to rank the most important practices and severe barriers were carried out.

\section{A. Data analysis techniques}

The objectives of the study were achieved through the analysis using the following statistical techniques and indices:

Relative Importance Index: This formula is used to rank the current practices of maintenance management based on importance indicated by the respondents

Relative Importance Index $(\mathrm{RII})=\Sigma \mathrm{W} /(\mathrm{A} * \mathrm{~N})$

Where $\quad \mathrm{W}=$ weightage given to each response (ranges 1 to 5); $\mathrm{A}=$ highest response integer (5), $\mathrm{N}=$ the total number of responses. The ranking of importance of maintenance practices derived from the RII. Many researchers use this index as the analysis techniques as it can rank the level of importance of the perceptions and practices and on various factors indicated by the respondents (30) (23).

Severity Index: This formula is used to rank the barriers based on severity indicated by the respondents

Severity Index (S.I) $(\%)=\Sigma \mathrm{a}(\mathrm{n} / \mathrm{N}) * 100 / 5$

Where $\mathrm{a}=$ constant weight given to the responses (ranges from 1 to 5), $\mathrm{n}=$ frequency of responses, $\mathrm{N}=$ total number of responses. By using the SI, the researcher ranked the barriers faced by the department during the maintenance implementation. Notably, the ranking allows the researcher to rank the highest potential barriers based on its severity level (31).

\section{B. Results of the study}

The questionnaires were distributed to the maintenance department of 149 local authorities, and only 77 responses were recorded $(51.68 \%$ response rate). The respondent consists of maintenance managers and personnel of three different categories of the local authority.

\section{Section A: Demographic background}

Table II shows the demographic background of the respondents from the survey. Most of the respondents are consist of $35 \%$ of diploma holders and $31.2 \%$ of bachelor's degree. Hence, they are recognized as knowledgeable and experienced in the field. However, most of the respondents are less than five years' experience with $33.8 \%$. The reliability of the respondents was still acknowledged since the experience of 6 to 15 years is $45.5 \%$. With the knowledge that they have, they can give the opinion in answering the research questions. Majority of the respondents are working in the tactical level of management with $51.9 \%$, which demonstrates they are very appropriate as they work closely in the maintenance management. Apart from that, the highest responses of $50.6 \%$ show the respondents are from the background of Civil and Structural Engineering.
Table II Demographic background of the respondents

\begin{tabular}{lcc}
\hline \multicolumn{1}{c}{$\begin{array}{c}\text { Demographic } \\
\text { background }\end{array}$} & Frequency & $\begin{array}{c}\text { Percentage } \\
\text { (\%) }\end{array}$ \\
\hline Level of Education & 16 & 20.8 \\
Master & 24 & 31.2 \\
Bachelor & 27 & 35.0 \\
Diploma & 5 & 6.5 \\
Certificate & 5 & 6.5 \\
SPM & & \\
Level of Management & 20 & 26.0 \\
Strategic & 40 & 51.9 \\
Tactical & 17 & 22.1 \\
Operational & & \\
Working Experience & 26 & 33.8 \\
Less than 5 years & 20 & 26.0 \\
6-10 years & 15 & 19.5 \\
11-15 years & 16 & 20.7 \\
16-20 years & & \\
Academic Background & 18 & 23.4 \\
Architecture & & \\
Civil and structural & 39 & 50.6 \\
engineering & & \\
Mechanical and & 5 & 6.5 \\
Structural Engineering & 2 & 2.6 \\
Facilities Management & 1 & 1.3 \\
Asset Management & 5 & 9.1 \\
Quantity Surveying & 7 & \\
Others & &
\end{tabular}

Section B: Current Practices of Maintenance Management by Local Authority

As shown in Table III, the importance of maintenance implementation in their organization shows by means score of the 45 practices varied from 3.93 (the highest) to 2.64 (the lowest) out of range of 1.0 indicating very not important to 5.0 indicating very important. The mean value has been set with categories to indicate the level of agreement to show the distinctions and practical evidence in the scale of 5: Very important $(M>4.20)$; Important (4.20 $\square \mathrm{M}<3.40)$, Moderate $(3.40 \square \mathrm{M}<2.60)$; Not important $(2.60 \square \mathrm{M}<1.81)$; Very not important $(1.80 \square \mathrm{M}<1.00)(31)$. 
Table III The current practices of maintenance management by the local authority

\begin{tabular}{|c|c|c|c|c|}
\hline 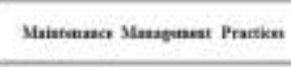 & Mean Scter & $\begin{array}{l}\text { Sesedard } \\
\text { Dentiatien }\end{array}$ & $\begin{array}{l}\text { Retaitic } \\
\text { leppertance } \\
\text { bedex }\end{array}$ & Rank \\
\hline \multicolumn{5}{|l|}{ 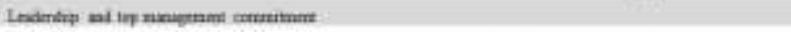 } \\
\hline Pesereant ind expecutin & $3.6 n$ & 0796 & 0.7605 & I \\
\hline Corranthed axtion" & 1.78 & $0 . \times 41$ & 0758 & , \\
\hline 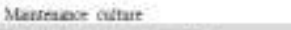 & 383 & o.sut & 0.7658 & 1 \\
\hline \multicolumn{5}{|l|}{ 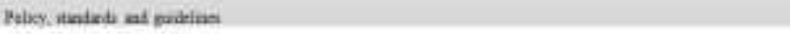 } \\
\hline 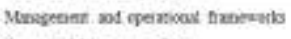 & 3.122 & 2003 & ели & 3 \\
\hline 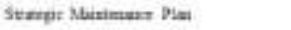 & 1.51 & ब65 & 0.7968 & $i$ \\
\hline Progan numamai oxph & 164 & om & 07200 & 2 \\
\hline \multicolumn{5}{|l|}{ Ongaunectal muagman } \\
\hline Marmmunct dopurnem requensen & 3n & axs & exoos & 3 \\
\hline Orpansational mutris & 3.9 & 6.798 & $075 x$ & $z$ \\
\hline 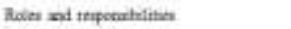 & 195 & $\sin$ & $a m ?$ & 4 \\
\hline Oyaniseno cortandichuer & 387 & 0.88 . & ems? & 1 \\
\hline \multicolumn{5}{|l|}{ 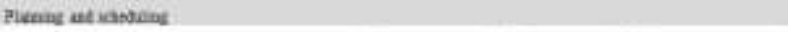 } \\
\hline Cootan mumant & 15 & $a m$ & $0, \pi e s$ & 1 \\
\hline 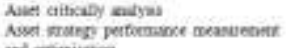 & 3.62 & 0.25 & 0.5237 & $s$ \\
\hline and optriniation & $3 \neq 3$ & 0.737 & 6647 & 6 \\
\hline 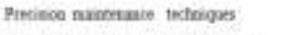 & 37 & asus & 0.7421 & 3 \\
\hline 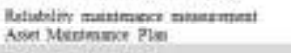 & $\frac{3.62}{375}$ & $\begin{array}{l}0.855 \\
0.002\end{array}$ & $\begin{array}{l}0.942 \\
07538\end{array}$ & $\vdots$ \\
\hline \multicolumn{5}{|l|}{ Plescutn Heapmed } \\
\hline Work ceordoation & 3,72 & orno & Q.744 & 2 \\
\hline Oubercie & Ins & $0855^{\circ}$ & 6.8369 & 5 \\
\hline Skita nat quatenes & 3 in & a 762 & ง จุม & 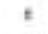 \\
\hline 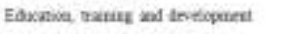 & 3.69 & 0700 & 27283 & 3 \\
\hline 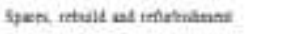 & 3.06 & 2807 & anes & + \\
\hline Twets aet coupnent & 300 & 0762 & 37932 & 3 \\
\hline \multicolumn{5}{|l|}{ Wiek manganat } \\
\hline Censtim mastrasase & $1 \times 2$ & 0.23 & a.met & + \\
\hline Piestant miestavace & 3.68 & 0716 & 9.7165 & s: \\
\hline 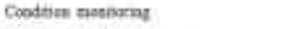 & 353 & 0.001 & कब्रथा & $=$ \\
\hline Work eanance as clewent & 349 & 0.022 & 9.7519 & , \\
\hline Cosertaclet marapmante. & $2 \times 0$ & o.7ne & a.2.8et & 1 \\
\hline Parenove natugeane & 393 & $a \operatorname{sen}$ & 3,74 & 2 \\
\hline Barelog naragrami & 204 & tos & 45355 & s \\
\hline \multicolumn{5}{|l|}{ Intamatam rasagonvet } \\
\hline 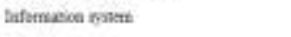 & 3.84 & 0.004 & 4.796 & 1 \\
\hline Con da & 304 & 2000 & acosts & 5 \\
\hline Dovenest nnoseant & 3.47 & acose & 20283 & + \\
\hline Ileount tratagntren & 1at & 2067 & $2 m i$ & 2 \\
\hline 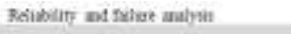 & 325 & art & 07310 & 2 \\
\hline \multicolumn{5}{|l|}{ Fisan-al sestind } \\
\hline Cont nesesenen & 358 & ats & 0.7158 & 4 \\
\hline Butge inchipes & 308 & ars & 07505 & t. \\
\hline Funb matscan & 330 & 0.617 & 0.6842 & 6 \\
\hline Cort quansunat & 538 & $0.8 \pi$ & a.6nos & 3 \\
\hline Cost comat & 361 & $0.8 \mathrm{~s} 4$ & 0.7211 & 3 \\
\hline Aseipur and feethad & 300 & $0 \%$ ใด & a.73i6 & 2 \\
\hline \multicolumn{5}{|l|}{ 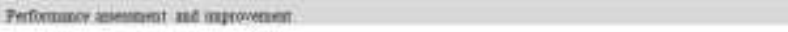 } \\
\hline Teosod ad segoreen & 353 & or & a.7oss & $t$ \\
\hline Baxitmaikay & 397 & 0.700 & 0.0737 & 4 \\
\hline 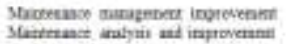 & 320 & ore. & 00528 & 5 \\
\hline & 3.59 & 0.094 & 0.679 & 2 \\
\hline 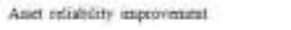 & 3.9 & 0.655 & 0.6700 & 3 \\
\hline
\end{tabular}

There are no practices that achieved the level of very important based on the mean score value higher than 4.20. Therefore, the current maintenance practices show that maintenance management is still lacking in those maintenance management areas. These findings implied that the top management must emphasize more on these practices and made the maintenance as the priorities to ensure the public facilities provided by them are in good condition. On the other hand, there are 37 practices that showed the important practices in the implementation of maintenance management within those local authorities in Malaysia. The elements of leadership and top management commitment, policy, standards and guidelines, organizational management, planning and scheduling and resources management are in the better state since the maintenance department still considers the maintenance needs to be carried out efficiently. The strategic and tactical level need to cooperate and make efforts in managing the maintenance activities.

Each of the element shows the ranking of the practices with almost in the same range as the index. The department indicates that they understand the requirement and expectation of the maintenance is very important to ensure the facilities can offer the best conditions to the public. Therefore, work management integration between three-tier management level (strategic, tactical and operational) ranked 1 as they believe that it is essential to work together to accomplish the primary objective of maintenance. Condition assessment is the key to the establishment of a maintenance plan before any maintenance activities can be carried out. Tools and equipment are considered the most important due to the small scale of maintenance activities which usually conducted by in-house, while contractor management is essential for the large-scale maintenance which generally outsourced. Many previous researchers agreed that the information management helps the maintenance activities to be done efficiently based on data information available; however, most of the local authorities still using manual recordkeeping. The RII shows that the budget is critical to ensure that the maintenance works can be executed based on requirements. By having feedbacks and responses from the implementation of maintenance, the performance of the maintenance can be evaluated, and any improvements can be made in future.

\section{Section C: Barriers in Maintenance Management}

Table IV shows the barriers faced by the maintenance department with the highest mean score of 4.22 (the highest) and 3.38 (the lowest). There are two barriers with a mean of very important, which are building age and building characteristics. Both barriers are related to building characteristics. Due to these barriers, most of the organization suffers a significant implication on the maintenance cost as substantial components of the building cost a massive amount of funds. Moreover, the local authority cannot control the weather condition and ageing factors of the buildings. Thus, the maintenance manager must ensure the maintenance tasks for the existing building to be more practical to safeguard its state from deteriorating, while other barriers show the average means score of the severity level of barriers faced by the maintenance department. 
International conference on Recents Advancements in Engineering and Technology (ICRAET-18) |15th and 16th March 2019|Siddhartha Institute of Technology \& Sciences, Telangana, India.

Table IV Barriers to Maintenance Management Practices

\begin{tabular}{|c|c|c|c|c|}
\hline Barrien & Shon & $\begin{array}{l}\text { Senadand } \\
\text { Deriatice }\end{array}$ & Serentit ladex (6) & Rank \\
\hline \multicolumn{5}{|l|}{ 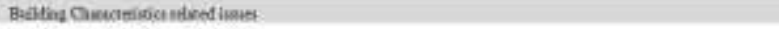 } \\
\hline Deriga atd renutretios & 3.68 & 1200 & 73.68 & 16 \\
\hline Sine and ane & 601 & 0.926 & $m \infty$ & 3 \\
\hline Butates we & $42 z$ & $\operatorname{ars} \theta$ & sets & 1 \\
\hline Midtes unt astental & $+2 z$ & 0704 & $84+7$ & 2 \\
\hline Elmat abd ravios & 393 & 0.999 & $\pi 50$ & 8 \\
\hline \multicolumn{5}{|l|}{ Mainmans mecour stand inas: } \\
\hline 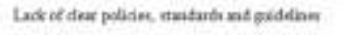 & in & a 70 & 700 & 9 \\
\hline Wedefond nimenose soutb & 393 & a.j7 & $76: 58$ & 30 \\
\hline 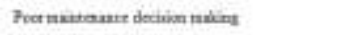 & 136 & 0.814 & 7536 & is \\
\hline rear werinuentity & 1.64 & ans: & 7208 & is \\
\hline 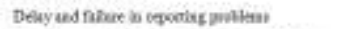 & 3.60 & $0552:$ & tows & 36 \\
\hline 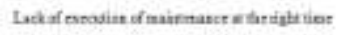 & हो) & aTs & 70.42 & 17 \\
\hline 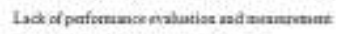 & sov & 0.615 & 784 & $s 9$ \\
\hline 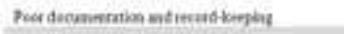 & 338 & 0618 & 71 is & $x$ \\
\hline \multicolumn{5}{|l|}{ Pondic reluted hien } \\
\hline 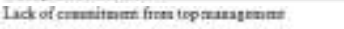 & $3+3$ & 0 TS4 & 69.22 & 24 \\
\hline 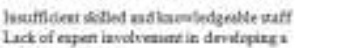 & $3 \pi$ & 0.09 . & 3913 & $n$ \\
\hline mainimuoce ylat. & 395 & 0.092 & 7893 & 6 \\
\hline 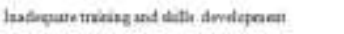 & 394 & 0.81 & Fits & 7 \\
\hline Ledk of nivetrases chat & 380 & 0.966 & 6.0s: & n \\
\hline 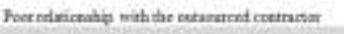 & 338 & oses. & 61.63 & 25 \\
\hline \multicolumn{5}{|l|}{ 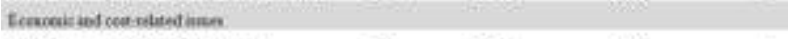 } \\
\hline 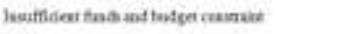 & 411 & asos & nit & 4 \\
\hline 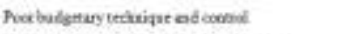 & 361 & 069 & n.1. & 38 \\
\hline 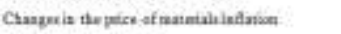 & 353 & aT:4 & sess & 22 \\
\hline 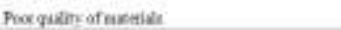 & 30 & $0 \pi 5$ & 19.98 & 14 \\
\hline \multicolumn{5}{|l|}{ 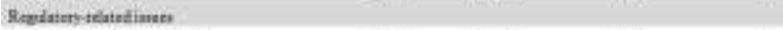 } \\
\hline Chaspris naineaser poligy & 3.76 & 0084 & $13 \times 6$ & 3 \\
\hline Cares it lefilution & 330 & $0.3 \pi$ & neon & 3 \\
\hline \multicolumn{5}{|l|}{ Otare retunat inarer } \\
\hline Vendalim & 4.13 & 0 Q83 & 1263. & 3 \\
\hline
\end{tabular}

While in Table $\mathrm{V}$, the barriers were ranked to show the most impacted barriers to the effectiveness of maintenance management. Building age $(84.74 \%)$ and building finishes and materials $(84.47 \%)$ ranked top as per agreed by most researches in the maintenance management area. The deterioration and technology advancements have caused a higher cost to implement the maintenance activities since it is very costly. Vandalism ranked third with $82.63 \%$ shows that this is a grave matter faced by the local authority since the user of the facilities tends to do damages and cause a loss due to multiple repairs and the replacement made. Education and awareness should be enhanced among the public as the public facilities are provided for their needs and comfort. Insufficient funds to support the maintenance activities and budget constraint $(82.11 \%)$ has proven that this barrier has caused the maintenance department to perform prioritization of maintenance works.
Table V Top tenth ranked barriers in maintenance practices

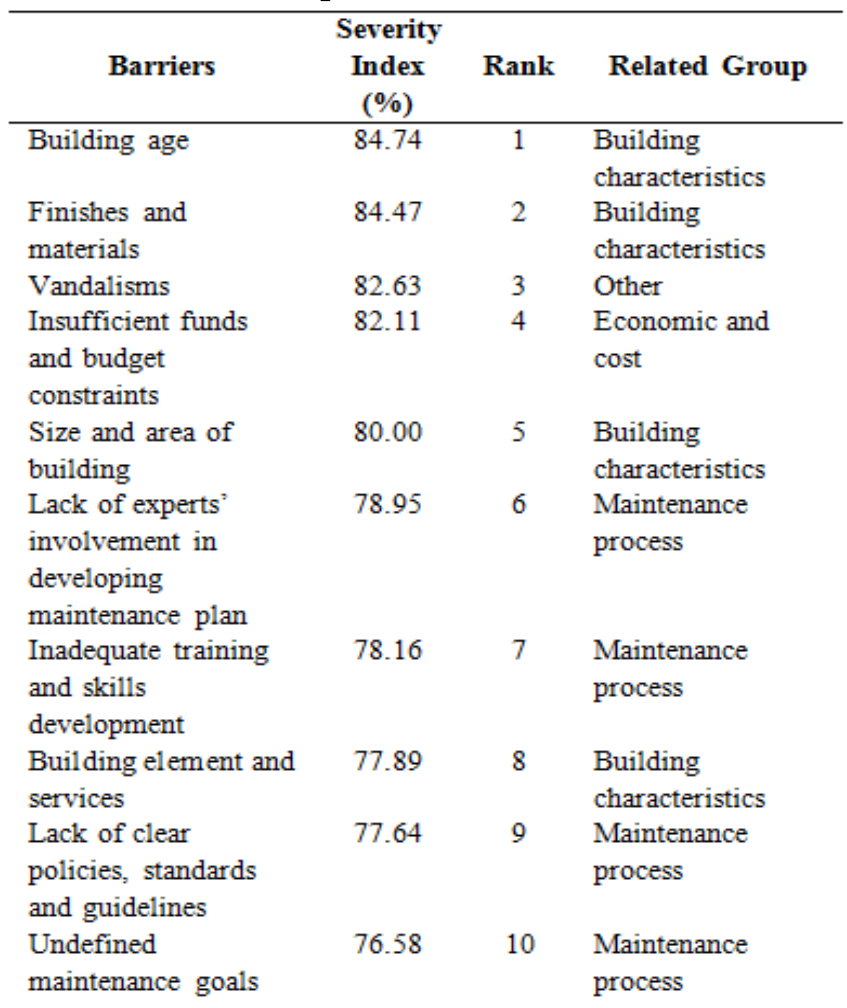

These tenth ranked barriers show that building characteristic and maintenance process are the crucial factors that predominantly hindering the maintenance department to implement effective maintenance management. The department must be able to identify these potential barriers at the preliminary stage and prioritize the maintenance as the primary focus to guarantee sustainable building performance and cost-effective. More efforts and attention should be highlighted while handling the maintenance.

\section{CONCLUSIONS}

This research is very significant because it is not only focusing on the current practices of maintenance management by local authorities but also on the barriers faced by them. Throughout the understanding of the current situation, the knowledge of the best practices allows the practitioner and researcher in evaluating and providing the best options for improvement. The knowledge can be extended by focusing on the efforts and deliver countermeasures to overcome the barriers towards the best practice and effective maintenance management. The importance of implementing the best practice of maintenance management can support safety and health assurance, cost effectiveness and sustainable performance of buildings. Future research should focus on the strategies to improve the maintenance management practices and extends the knowledge not only for local authority but also for various fields. 


\section{REFERENCES}

1. Barberá L, Crespo A, Viveros P, Stegmaier R. Advanced model for maintenance management in a continuous improvement cycle: Integration into the business strategy. Int J Syst Assur Eng Manag. 2012;3(1):47-63.

2. Majid RA, Mohamed N, Haron R, Omar NB, Jomitin B. Misappropriation of assets in local authorities: A challenge to good governance. Procedia - Soc Behav Sci. 2014;164(August):345-50. Available from: http://dx.doi.org/10.1016/j.sbspro.2014.11.086

3. Vadeveloo T, Singaravelloo K. Local Government and Community Development. Community Dev J. 2013;2(2):54-9.

4. Madureira S, Flores-Colen I, de Brito J, Pereira C. Maintenance planning of facades in current buildings. Constr Build Mater. 2017;147:790-802. Available from: http://dx.doi.org/10.1016/j.conbuildmat.2017.04.195

5. Olanrewaju AL, Abdul-Aziz A-R. Building Maintenance Processes and Practices. Building Maintenance Processes and Practices: The Case of a Fast Developing Country. 2015. 1-331 p. Available from: http://www.scopus.com/inward/record.url?eid=2-s2.084943262641\&partnerID=tZOtx3y1

6. Tan Sri Dato' Setia Ambrin Bin Buang. " Public Asset Management in Malaysia - an Audit Perspective ". 2011 p. 1-7.

7. Mohd-Noor N, Hamid MY, Abdul-Ghani AA, Haron SN. Building maintenance budget determination: An exploration study in the Malaysia government practice. In: Procedia Engineering. 2011. p. 435-44.

8. Adnan H, Fazry Z, Fauzi M, Rahmat I, Supardi A. Maintenance Management for Public Infrastructure. APRN J Eng Appl Sci. 2012;7(11):1514-22.

9. Noor Azlina. Aduan Diterima Pihak Berkuasa Tempatan (PBT)Mengikut Kategori - Set Data - MAMPU [Internet]. 28/10/2018. 2018 [cited 2018 Nov 24]. Available from: http://www.data.gov.my/data/ms_MY/dataset/aduanditerima-pihak-berkuasa-tempatan-pbt-mengikutkategori

10. Wordsworth P, Lee R. Lee's building maintenance management. 2001;

11. Seeley IH. Building Maintenance. The Maxmillan Press Ltd; 1987.

12. Lee HHY, Scott D. Overview of maintenance strategy, acceptable maintenance standard and resources from a building maintenance operation perspective. J Build Apprais. 2008;4(4):269-78.

13. Campos ML, Márquez AC. Review, Classification and Comparative Analysis of Maintenance Management Models. IFAC Proc Vol. 2008;41(3):239-44. Available from:

http://www.sciencedirect.com/science/article/pii/S14746 67015355725

14. Duffuaa SO, Ben-Daya M. Handbook of Maintenance Management and Engineering. Handbook of Maintenance Management and Engineering. 2009. 223235 p. Available from: http://www.scopus.com/inward/record.url?eid=2-s2.084892338874\&partnerID=tZOtx3y1

15. Kahn J. Applying Six Sigma to plant maintenance improvement programs. In: Proceedings MARCON 2006 - 3rd International Marketing Congress, Lahore, Pakistan. 2006. p. 19

16. Dunn S. 5 Keys to Lean Maintenance Improving Maintenance Productivity. Asset Manag Maint J. 2017;28(1):20-4.

17. Talamo C, Bonanomi M. Knowledge Management and Information Tools for Building Maintenance and Facility Management [Internet]. 2015. 211 p.
18. Tsang AHC. Strategic dimensions of maintenance management. Journal of Quality Maintenance Engineering. 2002;8(1):7-39. Available from: http://www.emeraldinsight.com/doi/full/10.1108/135525 10210420577

19. Marquez AC, Jatinder N. D. Gupta. Modern Maintenance Management for Enhancing Organizational Efficiency. Maintenance Management. 2004. 321-332 p.

20. Garg A, Deshmukh SG, Amik Garg and S.G.Deshmukh Maintenance management: literature review and directions. J Qual Maint Eng. 2006;12(3):205-38.

21. Abdul Lateef OA, Khamidi MF, Idrus A. Appraisal of the Building Maintenance Management Practices of Malaysian Universities. J Build Apprais. 2010;6(34):261-75. Available from: http://link.springer.com/10.1057/jba.2011.3

22. Lind $H$, Muyingo $H$. Building maintenance strategies: planning under uncertainty. Prop Manag. 2012;30(1):1428.

23. Sodangi M, Khamdi MF, Idrus A, Hammad DB, Ahmedumar A. Best practice criteria for sustainable maintenance management of heritage buildings in Malaysia. Procedia Eng. 2014;77:11-9. Available from: http://dx.doi.org/10.1016/j.proeng.2014.07.017

24. Rastegari A. Strategic maintenance management: Formulating maintenance strategy. 2015;(June 2016).

25. Aldairi J, Khan MK, Munive-Hernandez JE. Knowledgebased Lean Six Sigma maintenance system for sustainable buildings. Int $J$ Lean Six Sigma. 2017;8(1):109-30. Available from: http://www.emeraldinsight.com/doi/10.1108/IJLSS-092015-0035

26. Nagyova A, Pacaiova H. Maintenance evaluation based on the EFQM model excellence. IOP Conf Ser Mater Sci Eng. 2018;393:012005. Available from: http://stacks.iop.org/1757-

$899 \mathrm{X} / 393 / \mathrm{i}=1 / \mathrm{a}=012005$ ?key=crossref.c $2 \mathrm{edda} 12 \mathrm{e} 2 \mathrm{f} 2605$ d2afde03ea42af5a8

27. Yusuf GA, Mohamed SF, Yusof ZM, Misnan MS Adoption of Standard Based Pricing Method for the Procurement of Mechanical and Electrical Engineering Services in Malaysia. 2013;I:3-8.

28. Ngah K, Zakaria Z, Mustaffa J, Noordin N, Zool M, Sawal HM, et al. The Challenges of Local Authorities : A Case Study in Malaysia.. 2011;7(3):145-9. Available from: 10.3968/j.ccc.1923670020110703.170

29. Al-Turki U. A framework for strategic planning in maintenance. J Qual Maint Eng. 2011;17(2):150-62. Available from: http://www.emeraldinsight.com/doi/10.1108/135525111 11134583

30. Mkilania JN. Factors Affecting Best Maintenance Practice in Tanzania Public Sector. International Journal Mechanical Engineering Technololgy. 2016;7(3):139-49. Available

from: http://www.iaeme.com/IJMET/index.asp\%5Cnhttp://ww w.iaeme.com/IJMET/issues.asp\%5Cnwww.jifactor.com $\% 5 \mathrm{Cnhttp}: / /$ www.iaeme.com/currentissue.asp?JType=IJ MET\&VType $=7 \&$ IType $=3$

31. Marzouk MM, El-Rasas TI. Analyzing delay causes in egyptian construction projects. J Adv Res. 2014;5(1):4955. Available from: http://dx.doi.org/10.1016/j.jare.2012.11.005 